\title{
An audit evidence planning model for the public sector
}

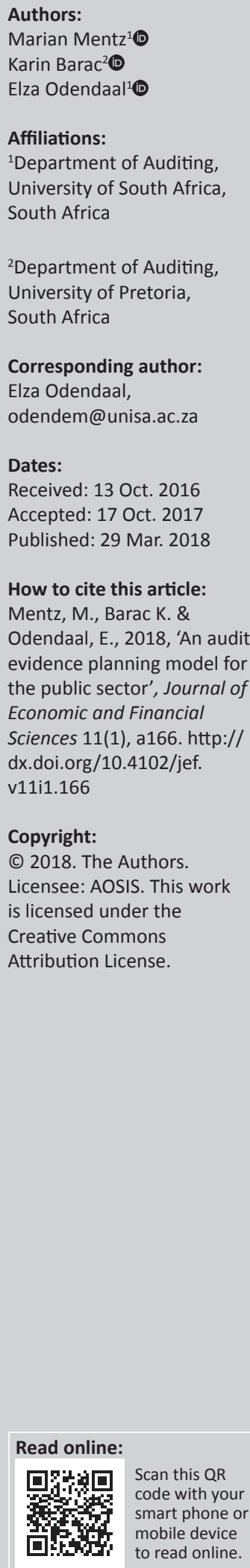

Orientation: Auditors have to exercise complex, multi-dimensional evidence-planning judgements.

Research purpose: Drawing on social closure theory, the aim of this study is to develop a model to inform the flexible exercise of judgement regarding the types, extent and combinations of audit procedures implemented to gather sufficient appropriate audit evidence to respond to the assessed risks of material misstatement.

Motivation for the study: The exercise of considerable judgements by auditors may mean that little consistency is achieved regarding the quantity and quality of the audit evidence obtained, especially in the public sectors of developing countries (which are often plagued by corruption), and where auditors and auditees have limited skills and experience.

Research approach, design and method: The study employs a theory-building approach to develop a model intended to guide public sector auditors (following an audit risk approach), to exercise planning judgements for a class of transactions, account balance and/or disclosure.

Main findings: The model clarifies the audit evidence decision-making sequences, interrelationships and contingent dependencies of the different audit procedures, and quantifies the compensatory inter-relationships between the types of audit procedures to be performed and the overall levels of assurance desired in response to the assessed risks of material misstatement.

Practical and managerial implications: The model could aid public sector auditors to reduce uncertainty, ambiguity and judgement errors during their planning decision-making.

Contribution or value-add: The model has been incorporated into the audit methodology of the Auditor-General of South Africa, and has been assessed for compliance with the International Standards on Auditing by the Independent Regulatory Board for Auditors in South Africa.

\section{Introduction}

Skills development is a fundamental necessity in developing countries, as it is central to capability enhancement and industrialisation, both of which ultimately increase national prosperity (Edigheji 2010). South Africa continues to experience a pervasive skills shortage, both as a legacy of apartheid and as a result of ongoing dysfunctionality in its education system (Akoojee 2010). This skills shortage continues to complicate the South African labour market, where most public sector employees lack appointment-appropriate experience (Koelble \& Siddle 2014), necessitating the use of private-sector consultants (Wenzel 2007).

The skills shortage and transformation challenges are closely interrelated and reverberate throughout the South African accounting profession, where the processes of closure on the basis of race and class are still prevalent (Barac 2015; Hammond, Clayton \& Arnold 2009; 2012). There is a shortage of professional accountants and auditors in the South African public sector, which emphasises the skills training needs of the public sector (World Bank 2013). Despite these challenges, South Africa has maintained its number one ranking for the strength of its Auditing and Reporting Standards for the sixth successive year according to the World Economic Forum's (WEF) Global Competitiveness Index for 2015-2016 (WEF 2015b).

Drawing on social closure theory and the above-mentioned paradox creates an interesting background for this study, which presents a model that is able to guide public sector auditors in

Note: This article is partially based on the author's thesis of the degree of Doctor of Commerce in Auditing at the University of South Africa, South Africa, with promoters Professors K. Barac and E.M. Odendaal, received 2014, available here: http://uir.unisa.ac.za/ bitstream/handle/10500/18477/thesis_mentz_m.pdf?isAllowed=y\&sequence=1 
the exercise of planning judgement for a class of transactions, account balance and/or disclosure. Such a model [referred to as an integrated evidence planning model (IEPM)] allows for an audit structure that is 'a mechanistic approach to decision making that constrains the range of actions available to individual auditors in specific circumstances' (Knechel 2007:386). By following a structured audit approach, auditors try to reduce the risk of serious errors in judgement within the audit process (Knechel 2000) and thereby reduce the uncertainties and ambiguities surrounding the performance of the responsibilities of inexperienced or unskilled professionals (Knechel 2007). Although the literature review identifies that today's auditors are resisting formalism and structure in favour of a business risk audit approach (Abdullatif \& Al-Khadash 2010; Khalifa et al. 2007; Knechel 2007), such a structured approach could aid public sector auditors in South Africa to sidestep both their own skills limitations and those of their auditees (World Bank 2013) when exercising judgement during their audit planning decision-making. The same applies in other developing countries where public sector auditors (also referred to as Supreme Audit Institutions [SAIs]) are faced with endemic limitations in skills which inhibit their performance of the tasks expected of a modern auditor (UN 2007). Sound auditor judgement is fundamental to the strengthening of public sector transparency and accountability (Iyoha \& Oyerinde 2010; Kayrak 2008) in developing countries as these countries are often plagued by corruption (ACFE 2014; Desta 2006; Pillay 2004; Transparency International 2014). It has become axiomatic that the sustainable economic development of these countries is impacted by weak accounting and auditing capabilities, and the consequential high incidence of financial mismanagement in public sectors (Iyoha \& Oyerinde 2010).

An auditor should obtain sufficient appropriate audit evidence to reduce audit risk to an acceptably low level; this will then enable him to draw reasonable conclusions on which the audit opinion can be based (Causholli \& Knechel 2012; Hayes 2007; Perry 2011; Schmutte \& Duncan 2009). Thus, the assessment of the risks of material misstatement informs the audit evidence planning decisions (Blay, Kizirian \& Sneather 2008; Fogarty, Graham \& Schubert 2007; IAASB 2015c; 2015e). Despite the importance of audit evidence planning considerations, previous studies have not shown a clear relationship between evidence planning and the extent of testing on one hand, and the level of or changes in risks on the other hand (De Martinis, Fukukawa \& Mock 2011; Elder \& Allen 2003; Fukukawa, Mock \& Wright 2006; Hogan \& Wilkins 2008; Johnstone \& Bedard 2001; Luo 2011; Seidel 2014); nor have they addressed the question of how to combine or aggregate evidence from different sources (Knechel 2007; Srinidhi \& Vasarhelyi 1986; Turley \& Cooper 1991) in order to reach a final audit opinion. Although the International Standards on Auditing (ISAs) provide some guidance to assist the auditor in deciding the sufficiency and appropriateness of audit evidence to be obtained, they do not dictate exactly how much evidence needs to be gathered, nor the quality thereof (Perry 2011). The basis for determining 'sufficient appropriate evidence' is therefore determined by the professional judgement of the auditor, which may mean that there is little consistency regarding the quantity and quality of the audit evidence obtained (Perry 2011), especially where auditors are inexperienced or lack the necessary skills. Recent research indicates that audit quality is not improving in areas where the auditor needs to apply judgement (Kleinman, Lin \& Palomon 2014). Consequently, there is a need to develop and communicate overarching principles to guide auditors making these decisions. This is in line with the aforementioned objective of this study.

The remainder of the article is organised as follows. In the next section, social closure theory, as the theoretical underpinning of this study, is explained. This is followed by an explanation of the research method and the context of the study. The building blocks of the model are explained next, with particular reference to the literature on the exercising of judgement by the auditor when planning the audit. Then the suggested model, intended to guide public sector auditors when exercising planning judgement, is presented. In the final section, a conclusion is reached and areas for future research are identified.

\section{Social closure theory}

Social closure theory, based on the work of Weber, is used to analyse social stratification processes (Murphy 1984). This theory posits that one group monopolises advantages by closing off opportunities to another group, deemed to be 'outsiders' (Malsch, Gendron \& Grazzini 2011:201). The apartheid laws in South Africa serve as an example of the effective application (and institutionalisation) of the principle of exclusion (Murphy 1984). Even though statutory apartheid was abolished in 1994, there is still evidence of 'widespread de facto segregation' in the post-apartheid era (Dixon et al. 2010:405). This manifests as workplace inequality and discrimination, is based on race and results in professional closure (Dixon et al. 2010). The situation reflects the imbalances within the South African education system (Mdepa \& Tshiwula 2012). The legacy and echoes of apartheid are thus still reflected in South Africa's ongoing skill shortages (Akinyemi 2010). Exclusion based on skill shortages is a product of the entire education sector that is still undergoing transformation. South Africa's past continues to hinder certain students from accessing and participating in the higher education sector, and many students arrive at higher education institutions underprepared for their studies (Mdepa \& Tshiwula 2012; Pym \& Kapp 2013; Sartorius \& Sartorius 2013). An assessment of the quality of mathematics and science education in South African schools, published in the Global Information Technology Report 2015, ranks South Africa in last position (mathematics) and close-to-last (science) (respectively 139th and 143rd of the 143 countries surveyed): when looking at the overall quality of South Africa's education system, this serves as a clear indication of the magnitude of this problem (WEF 2015a).

Professional closure is a particular genre of social closure (Chua \& Poullaos 1993; Hammond et al. 2012; Kim 2004; Lee 
2010; Macdonald 1984; Verhoef 2013) which was initially based on class, gender, race and social differentiations (Annisette 2003; Cooper \& Robson 2006). More recently, professional closure has come to embody exclusion based on education and professional credentials (Annisette 1999; Bonnin \& Ruggunan 2013). Through accredited education programmes, stringent examinations, prescribed practical training and the registration or licensing of those then deemed worthy of being called professional practitioners, closure or exclusion continues to be held in place in today's South African accounting profession (Heathcote 2012). Indications are that, even in post-apartheid South Africa, the professional closure of the South African accounting profession continues because of difficulties experienced by previously disadvantaged persons to acquire the academic education (South Africa's education system remains largely dysfunctional, as previously mentioned) and professional credentials necessary to enter the profession (Barac 2015). The shortage of professional accountants and auditors is especially apparent in the South African public sector (World Bank 2013). This is reflected in the membership statistics of the South African Institute of Chartered Accountants (SAICA): of its 32079 members, only 1415 (4\%) members work in the public sector, and of the 10189 members practicing as auditors, only $584(6 \%)$ are in the public sector (SAICA 2016).

\section{Research method}

This study employs a theory-building approach (Strauss \& Corbin 2008) to develop a model capable of guiding public sector auditors in the exercise of their planning judgement decisions for a class of transactions, account balance and/or disclosure. This study critically analyses and interprets the various relevant principles and concepts emerging from the literature (Leedy \& Ormrod 2014) and then systematically links and integrates them in successive stages through the application of inductive reasoning, deliberate thinking and logical interpreting to construct the IEPM that quantifies (explains) the extent of audit evidence required to support a desired outcome.

\section{Context of the study}

The model reported on in this article was developed for incorporation into the audit methodology used by the Auditor-General of South Africa (AGSA) (Mentz 2014). In terms of the Constitution of the Republic of South Africa (Act No. 108 of 1996), the AGSA acts as the external auditor of all national and provincial state departments, public entities, municipalities and any other institutions required by legislation to be audited by the AGSA (RSA 1996). The AGSA has to submit audit reports to any legislature that has a direct interest in the audit outcome, and to any other authority prescribed by national legislation; in addition, all reports must be made public (RSA 1996). The functions of the AGSA are described in section 188 of the Constitution; it is furthermore subject to the requirements of the Public Audit Act (Act No. 25 of 2004) (PAA), which mandates the AGSA to perform constitutionally required audits and other functions (RSA 2004).

The AGSA's staff complement, including trainee auditors and short-term contractors, was 3435 on 31 March 2015. Their focus is mainly on the performance of financial audits, performance audits, audits of performance information and audits of compliance with legislation (AGSA 2015a). Even though the AGSA experiences a scarcity of skills in some areas, by recruiting 1126 employees in 2014-2015 (33\% of the full staff complement is thus relatively inexperienced) it manages to ensure that the institution's staffing levels are adequate for effective performance of its statutory and other duties (AGSA 2015a). The organisation has, over the past years, managed to significantly increase the number of qualified audit professionals that make up its staff complement (in 2015, 547 staff members were chartered accountants [the SAICA website on 31 March 2016 reported this as 584 chartered accountants (SAICA 2016)]). Thus, $16 \%$ of the staff could practice as private sector auditors (AGSA 2015a).

In terms of the PAA, the AGSA determines the standards and methodology applied in audits of public sector entities (RSA 2004). The AGSA is one of a few SAIs in the world that has fully implemented the ISAs (AGSA 2015a). Although having no legal oversight role over the AGSA, the Independent Regulatory Board for Auditors (IRBA) in South Africa reviews and provides credibility to the internal quality control monitoring process the AGSA uses (this is also performed at the individual private sector firm level) (World Bank 2013). That the IEPM adheres to the ISA's requirements is confirmed by the fact that the model has been incorporated into the audit methodology of the AGSA, and this methodology has been successfully assessed for compliance with the ISAs through a monitoring inspection performed by the IRBA (Mentz 2014).

The World Bank (2013) reported significant skills shortages in the South African public sector (auditees of the AGSA), which also manifests as a shortage of skills available to support financial management roles in public sector entities. Internal capacity constraints and high vacancy rates sometimes lead public sector entities to appoint consultants to support the continuity of service delivery, a practice which the World Bank (2013) considers a main cause of consistently poor audit outcomes in the three tiers of government. For example, $17 \%$ of the 325 auditees at local government level (268 municipalities and 57 municipal entities) received unqualified audit reports with no findings in the 2013 and 2014 financial year. For the 2012 and 2013 financial year, this percentage amounted to 9\% and 5\% for the 2011 and 2012 financial year (AGSA 2015b). Even though since 2011 and 2012 the number of municipalities and municipal entities achieving what is commonly called a 'clean audit' has more than tripled, and a quarter of all public departments and entities have attained a clean audit status, these audit outcomes remain areas of concern (World Bank 2013). 


\section{Building the model to guide public sector auditors when exercising planning judgement Introduction}

This article reports on a model developed to guide public sector auditors when required to exercise planning judgement for a class of transactions, account balance and/or disclosure. In the following sections, the steps to be followed (identified as seven building blocks) to construct the IEPM are discussed. This is performed in the context of recently published literature.

\section{Risk assessment and materiality}

In terms of the ISAs (IAASB 2015c), the auditor should obtain (or be in possession of) an understanding of the entity and its environment, and should then use his knowledge to assess the risks of material misstatement at both the overall financial statement level and at assertion level for all classes of transactions, account balances and disclosures. In planning and executing the audit, the auditor should focus on those areas of the financial statements where the risk of misstatement is the greatest (Bowlin 2011; Fogarty, Graham \& Schubert 2006). The risk assessment phase of the audit is therefore an integral part of evidence gathering as it directs the auditor's attention to issues that require further investigation (Fogarty et al. 2006). Risk assessment is the 'descriptive lens' (Budescu, Peecher \& Solomon 2012:19) by which auditors plan and execute the audit. However, when planning the audit approach and selecting the most appropriate audit evidence-gathering mix, the auditor should keep efficiency and effectiveness considerations in mind (El-Masry \& Hansen 2008; Hayes 2007). During the audit a continuous, dynamic and recursive process of risk assessment is followed, with a corresponding update to the risk response that the auditor implements, to obtain sufficient appropriate audit evidence (Bell, Peecher \& Solomon 2005; IAASB 2015c).

The risk-based approach also improves audit quality in that it guides the determination of what constitutes a sufficient and appropriate audit response to the auditor's understanding and assessment of client risks (De Martinis et al. 2011; Knechel et al. 2013). Thus, the risk-based audit approach encapsulates the deduction that audit efficiency and effectiveness (and thus ultimately audit quality) are determined by an appropriate and sufficient response to the auditor's understanding and assessment of the client's risks, when he is obtaining audit evidence.

Materiality is pervasive throughout the audit process, from planning the audit to evaluating the results of audit testing when formulating the audit opinion (Del Corte, García \& Laviada 2010). The auditor's determination of what is 'material' is a matter of professional judgement (Houghton, Jubb \& Kend 2011; IAASB 2015a). As the auditor's judgement of materiality should be influenced by the needs of the users of the financial statements, materiality judgements must be accommodating of surrounding circumstances and must consequently involve both quantitative and qualitative considerations (Houghton et al. 2011; IAASB 2015d). Such a multi-faceted approach to materiality assessment is well supported by researchers and regulatory bodies (Acito, Burks \& Johnson 2009; Del Corte et al. 2010; IAASB 2015d, 2015f.; Zabel \& Benjamin 2002).

In line with the Conceptual Framework for Financial Reporting (IASB 2015), the ISAs consider misstatements in the financial statements to be material if they individually or as a whole influence the economic decisions of users of the financial statements (IAASB 2015d). During the planning stage, the auditor's judgement regarding materiality influences the level (both in quantity and quality) of evidence to be collected in order to support the audit opinion (IAASB 2015d; Messier, Martinov-Bennie \& Eilifsen 2005). The extent of audit evidence required to obtain reasonable assurance that the financial statements do not contain a material misstatement varies inversely with the auditor's materiality judgement (Blokdijk, Drieenhuizen \& Dan 2003):

First building block: Based on a risk assessment at the overall financial statement level, perform a risk assessment at assertion level for classes of transactions, account balances and disclosures, and distinguish between two risk categories, namely, 'significant' and 'non-significant'.

Second building block (a): Based on a 'significant' risk assessment at the overall financial statement level, consider the classes of transactions, account balances and disclosures as 'material' and identify the risk level as 'significant'.

Second building block (b): Based on a 'non-significant' risk assessment at the overall financial statement level, determine whether the classes of transactions, account balances and disclosures are material, and identify the risk level as 'standard' for material and 'slight' for non-material.

\section{Combination of audit procedures}

Audit evidence planning requires the exercise of professional judgement when determining the types of procedures to be performed during the course of the audit. Assurance may be drawn from tests of controls and substantive procedures, with the latter providing a further choice between analytical procedures and tests of details. While tests of controls and tests of details focus on the individual control activities and transactions that result in the recorded financial statement amounts (Akresh 2010; Kinney 1979), analytical procedures do not consider the details of the individual transactions that comprise the recorded amount (Brewster 2011; Dănescu \& Spătăcean 2009; Glover et al. 2005; Messier, Simon \& Smith 2013).

The auditor's assessment of the risks of material misstatement, based on his or her understanding of the entity's internal controls, provides an indication of whether or not the controls are properly designed, implemented and/or if they are operating effectively (IAASB 2015e). That is, the results of the risk assessment procedures require the auditor to exercise 
judgement as to whether or not to test the operating effectiveness of controls by performing tests of controls, thereby determining the nature, timing and extent of substantive procedures. The basic audit approach alternatives are either to perform tests of controls [and thereby limit substantive procedures (a combined approach)] or to perform only substantive procedures (a substantive approach). (The exception is that a combined approach is compulsory when an entity conducts its business using information technology [IT] and no documentation of transactions are produced or maintained, other than through the IT system [IAASB 2015e]). It provides the auditor with six different combinations of procedures to gather audit evidence, as depicted in Table 1.

As substantive procedures must always be performed for each material class of transactions, account balance and disclosure (IAASB 2015e), performing tests of controls is generally more efficient and effective only if the audit time and effort saved by limiting substantive procedures exceeds the time and effort spent in performing the tests of controls, or if the tests of controls provide assurance on more than one assertion, class of transactions, account balance or disclosure (O'Reilly et al. 1999). The preference for the performance of extensive substantive procedures (when the auditor judges testing controls to be inefficient and ineffective) is supported both by the literature (AICPA 2008; Eilifsen et al. 2010) and the ISAs (IAASB 2015e).

The auditor should also decide on the mix of analytical procedures and tests of details that is most efficient and effective in obtaining the full extent of audit evidence required to reduce audit risk to an acceptable level. Although analytical procedures commonly provide an efficient means of obtaining assurance (Cho \& Lew 2000; Lin \& Fraser 2003; Trompeter \& Wright 2010), they are generally more applicable to large volumes of transactions that tend to be predictable over time (IAASB 2015g). The literature has also shown that auditors are reluctant to apply them because they regard them as costly and time-consuming (Knechel 2007; Wang \& Cuthbertson 2014). In contrast, tests of details are typically more effective in providing a higher level of assurance, even if they are less efficient (Eilifsen et al. 2010). In a recent study, Christensen, Elder and Glover (2015) found that auditors rely heavily on tests of details than on other types of substantive procedures such as analytical procedures. Evidence planning requires the exercise of judgement regarding the interrelationships between the different types of audit procedures (tests of controls, tests of details and analytical procedures) that are performed in response to the assessed risks. The auditor will reconsider the mix of audit procedures when audit tests yield unsatisfactory results (IAASB 2015e).
Third building block: Based on the risk assessment at assertion level for classes of transactions, account balances and disclosures, identify the appropriate audit approach (combined or substantive):

- Significant risk level - employ a combined approach (test of controls and substantive tests [tests of details and analytical procedures]) or substantive approach (tests of details and analytical procedures).

- Standard risk level - employ a combined approach or substantive approach (as described above).

- Slight risk level - employ a substantive approach (substantive tests [tests of details and analytical procedures]).

\section{Relating types of audit procedures with levels of audit risk or assurance}

The nature and extent of audit evidence gathered by the auditor should be related to the level of assurance that is deemed sufficient to reduce the risk of expressing an inappropriate opinion to an acceptable low level (IAASB 2015b). Thus, during planning, the auditor should decide on an overall level of assurance desired or, alternatively, an overall level of audit risk that is acceptable. For a targeted overall level of assurance (or overall audit risk level) for a particular class of transactions, account balance, disclosure or assertion, there exists a compensatory relationship between the extent and types of audit procedures such that as more assurance is obtained from one type, less assurance is required from other types (Arens, Elder \& Beasley 2012; Eilifsen et al. 2010; IAASB 2015e).

Hooks (2011) states that planning is simplified if audit firms have guidelines regarding the level of audit risk they are willing to accept. Some firms express these risks using terms like 'high', 'moderate' and 'low' or 'substantial', 'moderate' and 'little', rather than using estimates of risk expressed as percentages (AICPA 2008; Elder \& Allen 2003). However, quantitative expressions of risks or levels of assurance are expected to provide more meaningful measures and to contribute to more consistent communications within audit teams. This leads to more effective quality control, thereby potentially bringing about more efficient and effective audits (Fukukawa \& Mock 2011). To this end, Eilifsen et al. (2010) recommend a percentage interval of $90 \%-95 \%$ for a high level of assurance, $80 \%-85 \%$ for a moderate level of assurance and $70 \%-75 \%$ for a low level of assurance, while the audit sampling guide issued by the AICPA (2008) recommends $95 \%$ for a high level of assurance, $86 \%$ for a moderate level of assurance and $63 \%$ for a low level of assurance. Although the audit sampling guide issued by the

TABLE 1: Audit procedure combinations.

\begin{tabular}{|c|c|c|c|c|c|c|}
\hline \multirow[t]{3}{*}{ Types of procedures } & \multicolumn{6}{|c|}{ Audit evidence gathering approaches } \\
\hline & \multicolumn{3}{|c|}{ Combined approaches } & \multicolumn{3}{|c|}{ Substantive approaches } \\
\hline & Approach 1 & Approach 2 & Approach 3 & Approach 4 & Approach 5 & Approach 6 \\
\hline Tests of controls & Yes & Yes & Yes & - & - & - \\
\hline Analytical procedures & Yes & - & Yes & Yes $^{+}$ & - & Yes \\
\hline Tests of details & - & Yes & Yes & - & Yes & Yes \\
\hline
\end{tabular}

$t$, This approach cannot be employed where the risk of material misstatement is significant (IAASB 2015e). 
AICPA is not authoritative under the ISAs issued by the IAASB, it is well accepted in practice (Hall, Hunton \& Pierce 2002; Hoogduin, Hall \& Tsay 2010). However, while the AICPA guidance does not assign descriptors to the risks and levels of assurance, when applying the AICPA guidelines, the IEPM assumes three distinct risk levels that imply three corresponding levels of assurance. This is illustrated in the fourth building block:

Fourth building block: Allocate an appropriate level of assurance (with a corresponding assurance factor) for a class of transactions, account balance or disclosure based on the identified risk level:

- Slight risk level: Slight (63\%) level of assurance with a 37\% acceptable level of audit risk = assurance factor 1 :

If the class of transactions, account balance or disclosure is not material by value and/or nature and does not require special audit consideration to respond to the assessed risk of material misstatement at the assertion level, this is the level of audit evidence that should be obtained.

- Standard risk level: Standard (86\%) level of assurance with a $14 \%$ acceptable level of audit risk $=$ assurance factor 2 :

A standard level of audit evidence is needed if the class of transactions, account balance or disclosure is material by value and/or nature and does not require special audit consideration to respond to the assessed risk of material misstatement at the assertion level.

- Significant risk level: Significant (95\%) level of assurance with a $5 \%$ acceptable level of audit risk = assurance factor 3 :

This is the level of audit evidence that is required if the class of transactions, account balance or disclosure is material by value and/or nature and, in the auditor's judgement, requires special audit consideration to respond to the assessed risk of material misstatement at the assertion level.

Fifth building block: Relate the assurance factor $(1,2$ or 3$)$ to the extent of assurance obtainable from the different audit evidence gathering combinations of tests of controls, tests of details and analytical procedures.

By combining building blocks 1-5, a quantified audit evidence mix matrix, depicted in Table 2, is achieved.

The above mathematical audit evidence mix matrix quantifies the individual overall levels of assurance (significant, standard and slight) corresponding with assurance factors 3 , 2 and 1 . This is also quantitatively related to the extent of assurance obtainable from the different audit evidence gathering combinations, and numerically links the level of assurance obtained from one type of procedure to the levels of assurance required from other types of procedures. This quantification of the levels of assurance directly influences the extent of audit evidence required. In addition, the mathematical audit evidence mix matrix quantitatively links the integration of the risk assessment process with the level of assurance required from performing audit procedures that will result in sufficient appropriate audit evidence on which the audit opinion can be based.

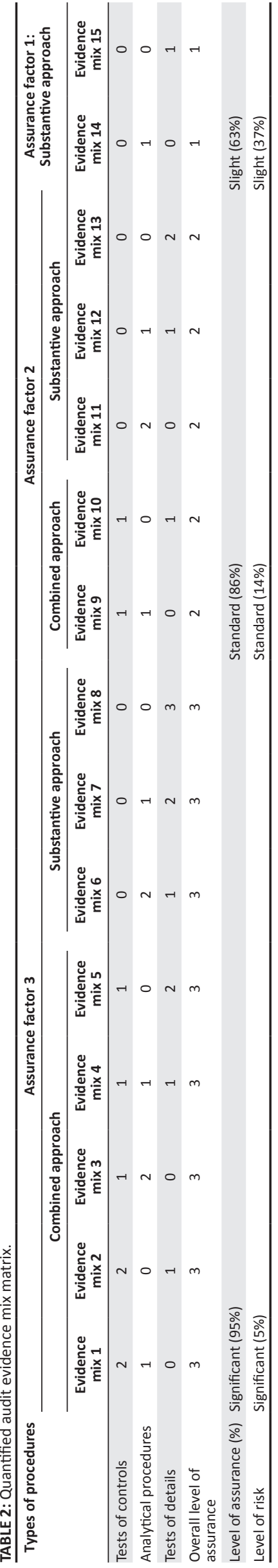


After establishing an acceptable overall level of audit risk or a desired overall level of assurance per class of transactions, account balances, disclosures or assertions, the next decision requiring the exercise of judgement from the auditor is how to relate the overall level of assurance required to the extent of assurance required from each type of procedure, as well as how to link the level of assurance obtained from one type of procedure to the extent of audit evidence required from other types of procedures.

\section{Extent of audit procedures}

Audit evidence planning requires the exercise of professional judgement to determine the extent to which each of the types of audit procedures should be performed during the course of the audit.

Analytical procedures: Analytical procedures are substantive procedures and involve the comparison of recorded financial statement amounts against expectations developed by the auditor through the analysis of plausible relationships (IAASB 2015g) among both financial and non-financial data (Messier et al. 2013). Analytical procedures are concerned with the reasonableness or the precision of the expectation developed by the auditor (Glover et al. 2005; McDaniel \& Simmons 2007). The higher the precision (i.e. the narrower the range of differences between the auditor's expectation and the recorded amount), the more effective the procedure will be in identifying potential misstatements in the recorded financial statement amounts and the greater the level of assurance provided by the procedure (Hitzig 2004). However, the determination of the precision interval is a subjective, judgemental assessment (Koskivaara 2007; Samaha \& Hegazy 2010).

The ISAs (IAASB 2015g) mandate that the auditor's determination of the size of the difference from the expectation that can be accepted without further investigation must be influenced by materiality, and must be consistent with the desired level of assurance. Based on the levels of assurance obtainable from analytical procedures (refer to Table 2), the corresponding risk percentages of expressing an inappropriate audit opinion are:

- Slight level of assurance (=1):

- Precision interval $=$ Recorded financial statement amount $\pm 37 \% \times$ materiality

- Standard level of assurance $(=2)$ :

- Precision interval $=$ Recorded financial statement amount $\pm 14 \% \times$ materiality

The application of the above percentages (i.e. $37 \%-14 \%$ ) to materiality in order to define precision intervals for the slight $(=1)$ and standard $(=2)$ levels of assurance is supported by the literature as sufficient and appropriate (Kinney \& McDaniel 1996; McDaniel \& Simmons 2007; Wilson \& Colbert 1989):

Sixth building block: Calculate the extent of analytical procedures required by determining the precision level.
Tests of controls and tests of details: The extent of tests of controls and tests of details is generally thought of in terms of sampling and the quantity of procedures to be performed in terms of sample sizes (IAASB 2015e). The underlying assumption of sampling is that the sample will allow accurate inferences to be made about the population (Colbert 2001; Whittington \& Pany 2010). The three key inputs to computing sample sizes are the desired level of assurance, the tolerable misstatement amount or the deviation rate (tolerable error), and the expected population misstatement amount or deviation rate (expected error). Judgement and the exercise of considerable insight are required to establish the appropriate values for these determinants as inputs in calculating appropriate sample sizes. The auditor must use a sample size that is sufficiently large to reduce the risk that the financial statements contain undetected material misstatements to an acceptable low level. Once the desired level of assurance has been decided, the appropriate sample size is mainly influenced by the difference between the expected error and the tolerable error, which is referred to as the precision of the sampling application (Eilifsen et al. 2010). There is an inverse relationship between tolerable misstatement (or deviation rate) and sample size (IAASB 2015h) and a direct relationship between the expected misstatement (or deviation rate) and sample size (IAASB 2015h).

The ISAs (IAASB 2014h) further require that the sample sizes for both non-statistical and statistical applications should be comparable. Therefore, although the auditor is not required to use statistical formulae or tables to identify the variables that will determine sample sizes under a nonstatistical approach, the auditor is required to apply his or her professional judgement and knowledge of the underlying statistical sampling theories, methods and assumptions in order to appropriately consider the three determinants of sample size in arriving at a non-statistical sample size that is comparable to the statistical sample size. Applying professional judgement in determining non-statistical sample sizes, particularly where the auditor does not have a sound basic knowledge of statistical sampling theories, methods and assumptions, raises concerns that sampling judgements across engagement teams may be inconsistent, and that sampling judgements may differ significantly from statistical sampling theory (AICPA 2008; Eilifsen et al. 2010; Whittington \& Pany 2010).

The IEPM employs a simple formula approach that is consistent with statistical sampling theories, methods and assumptions to determine non-statistical sample sizes for tests of controls that is quantitatively linked to the required overall levels of assurance. In this study, a non-statistical sampling model for tests of controls has been derived from both the sample size determinants of the desired assurance level and the tolerable deviation rate; these are fixed in line with sampling theories, methods and assumptions, as well as generally accepted auditing practice and global audit guidance, with only the decision regarding the expected 
deviation rate being left to the auditor's judgement. With reference to the tolerable deviation rate, Eilifsen et al. (2010) recommend that a tolerable deviation rate of between $3 \%$ and $5 \%$ should be used when a higher level of assurance is required from tests of controls, and that a deviation rate of between $6 \%$ and $10 \%$ should be used when a lower level of control assurance is needed. Arens et al. (2012) propose that the tolerable deviation rate lies between $4 \%$ and $6 \%$, while O'Reilly et al. (1999) suggest that there is a range of possible tolerable deviation rates lying between $5 \%$ and $10 \%$. Based on the near agreement of these suggestions, a tolerable deviation rate of $5 \%$ has been used in the model.

Just as non-statistical approaches are used for tests of controls, they are also applied in this study to tests of details. It is generally accepted that the following three-variable formula may be used to calculate a non-statistical sample size for tests of details (AICPA 2008; Arens et al. 2012; Eilifsen et al. 2010; IFAC 2011; Messier, Glover \& Prawitt 2010):

Sample size $=$ Recorded population size $\times$ Assurance factor $\div$ Tolerable misstatement (materiality)

Use of this simple formula increases the consistency between non-statistical sampling judgements (practice) with statistical sampling theory:

Seventh building block: Calculate the extent of tests of controls and/or tests of details by determining the sample size.

By combining the quantified audit evidence mix matrix depicted in Table 2 (building blocks 1-5) with building blocks 6 and 7 the IEPM is complete. For purposes of this article, the IEPM is depicted in Figures 1, 2 and 3. In terms of building blocks 1 and 2, the risk level of each assertion, class of transactions, account balance or disclosure is identified as 'significant', 'standard' or 'slight' as indicated in Figure 1.

If the risk level of an assertion, class of transactions, account balance or disclosure is identified as significant, the auditor follows a combined or a substantive approach as indicated in Figure 2.

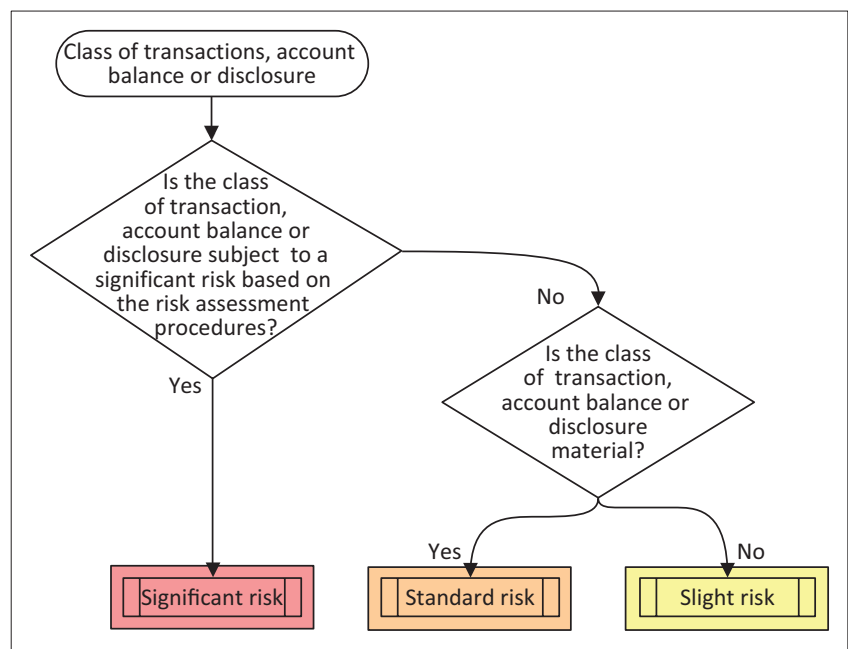

FIGURE 1: Building blocks 1 and 2 of the integrated evidence planning model.
Alternatively, if the risk level of an assertion, class of transactions, account balance or disclosure is identified as standard, the auditor may follow either a combined or a substantive approach, while a substantive approach is all that is required if the risk level is identified as slight, as indicated in Figure 3.

\section{Value of the integrated evidence planning model in the context of social closure theory}

The model quantitatively integrates the determination of the extent of audit evidence to be obtained with the assessed risks of material misstatement and the materiality of each assertion, class of transactions, account balance or disclosure. The risk level of each assertion, class of transactions, account balance or disclosure is identified as 'significant', 'standard' or 'slight' (first and second building blocks) and a corresponding quantitative level of assurance is allocated (fourth building block). Based on the identified level of assurance, the model quantitatively links the extent of audit evidence required to the sample sizes needed for performance of tests of controls and tests of details, and the precision levels needed for the performance of substantive analytical procedures (sixth and seventh building blocks). By establishing this inter-relationship between the risks of material misstatement and the assurance that is required to reduce audit risk to an acceptable low level, the IEPM increases the audit work in high-risk areas. This effectively addresses the situation identified in earlier studies that found no clear correlation between evidence planning and extent of testing and the level of or changes in risks (De Martinis et al. 2011; Elder \& Allen 2003; Fukukawa et al. 2006; Hogan \& Wilkins 2008; Johnstone \& Bedard 2001; Luo 2011; Seidel 2014).

In addition to incorporating the different types and combinations of audit procedures needed to obtain audit evidence in response to the assessed risks (third building block) and establishing the compensatory inter-relationship between types of audit procedures, the IEPM also quantitatively integrates the relative assurance being drawn from the different types of audit procedures (fifth building block). Thereby, the IEPM clarifies how to combine or aggregate evidence from different types of procedures in order to reach a final audit opinion. By following the IEPM, public sector auditors obtain guidance, enabling them to determine the extent of audit evidence required [which is linked to sample sizes (for tests of controls and tests of details) and precision levels (for analytical procedures)], in relation to the assessed risks of material misstatement. It aids the public sector auditor who is required to respond to the question of how much to test, and in so doing responds to numerous conclusions in scholarly literature that there is an increasing need for guidance in how to determine the extent of testing (Bierstaker, Houston \& Wright 2006; Charles, Glover \& Sharp 2010; CICA 1980; Fogarty \& Rigsby 2010; Hayes 2007; Kinney 2005; Seidel 2014). In addition, the IEPM answers the question 


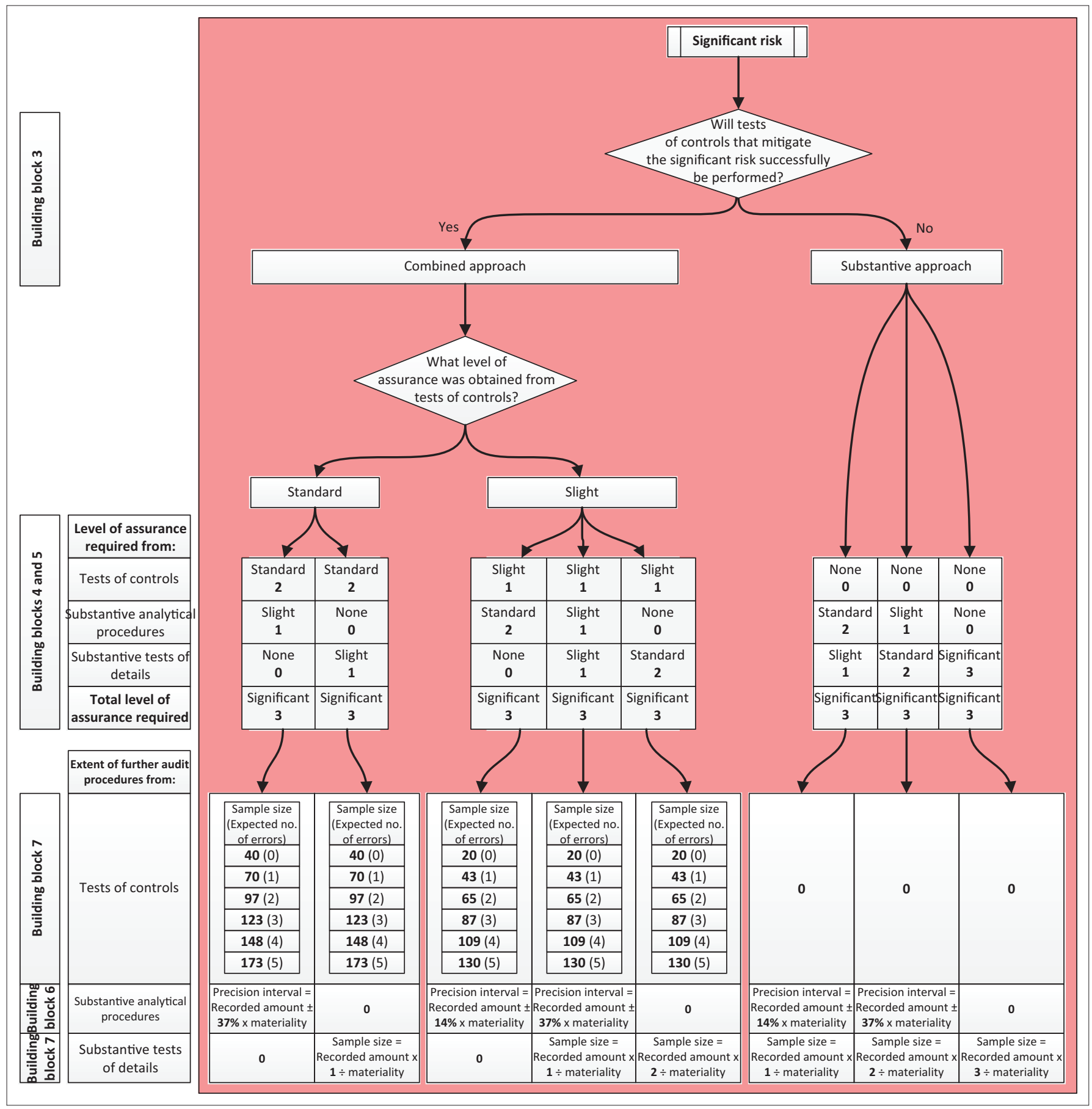

FIGURE 2: The integrated evidence planning model for significant risk assertions, classes of transactions, account balances and disclosures.

that arose from the literature review: how to combine or aggregate evidence from different types of procedures (tests of controls, substantive analytical procedures and tests of details) (Knechel 2007; Srinidhi \& Vasarhelyi 1986; Turley \& Cooper 1991) in order to reach a final audit opinion.

Thus, the IEPM provides a framework to guide the auditor's exercise of his judgement regarding audit evidence gathering. However, it is not a substitute for professional judgement. Rather, the model provides a framework within which the auditor may confidently approach the exercise of judgement (an area where 'flexibility' predominates) regarding the types, extent and combinations of audit procedures to be employed to gather sufficient appropriate audit evidence to respond to the assessed risks. Although audit decision-making cannot be reduced to the mechanical application of a quantitative model, and will always require the application of considerable (human auditor) judgement, studies have suggested that decision-making models that aid the auditor when required to exercise judgement in complex, multi-dimensional evidence planning situations may improve audit efficiency and effectiveness (Bedard \& Graham 2002; Curtis \& Turley 2007; Jeppesen 2007; Knechel 2007; Nelson, Tan \& Trotman 2005). The IEPM responds to this need. Furthermore, the model, which has now been incorporated into the audit methodology of the AGSA, is 


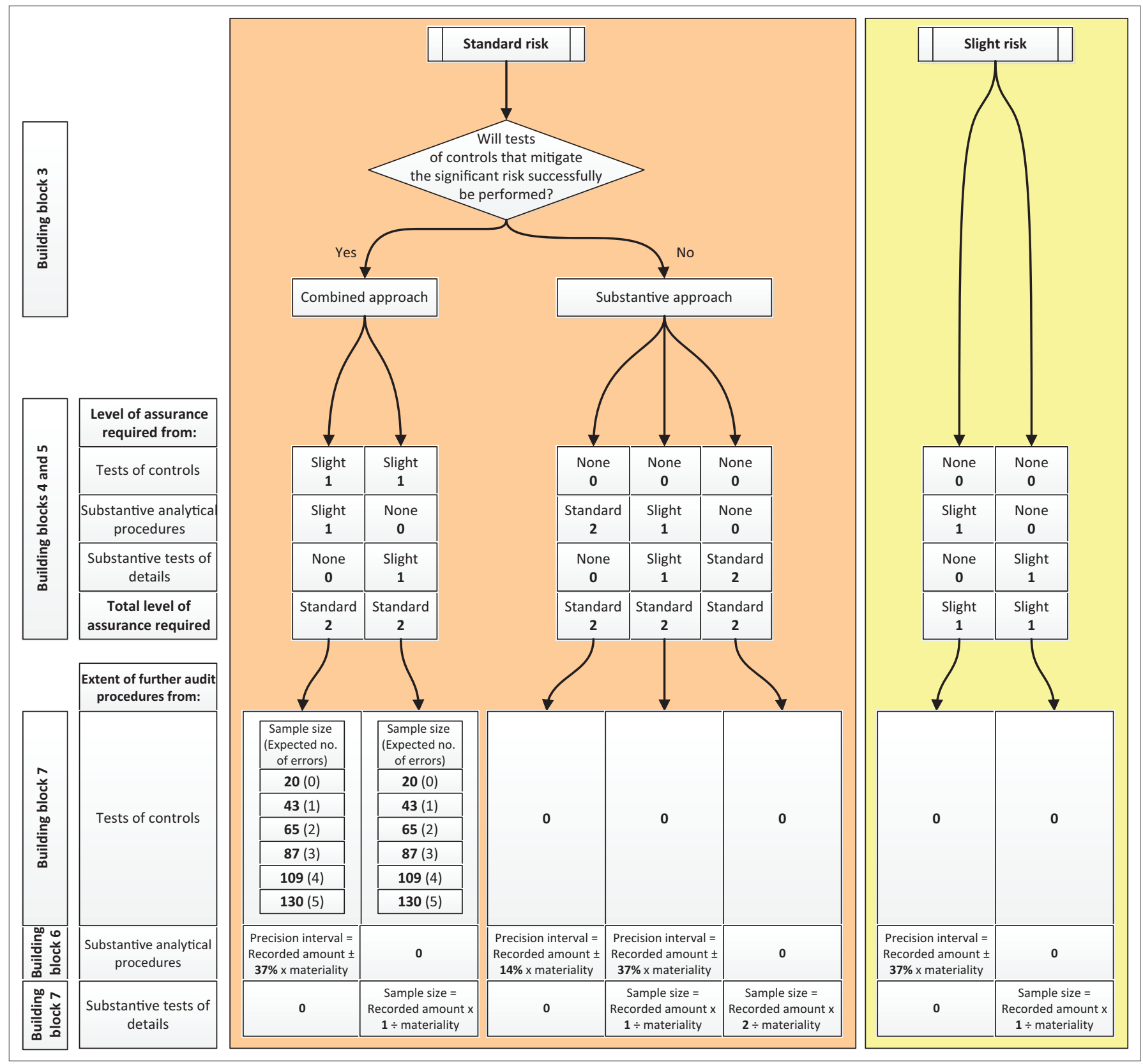

FIGURE 3: The integrated evidence planning model for standard and slight risk assertions, classes of transactions, account balances and disclosures.

also a practical tool to manage adherence to the ISAs (Mentz 2014). This has been confirmed by the IRBA's assessment of the model against established assessment criteria and standards, during the IRBA's review of the AGSA's audit methodology (Mentz 2014).

As is evident from the above discussion, the IEPM clarifies the audit evidence decision-making sequences, interrelationships and contingent dependencies of the different audit procedures. Furthermore, it quantifies the compensatory inter-relationships between the types of audit procedures and the desired levels of overall assurance required in response to the assessed risks of material misstatement. Such a direction is of value to inexperienced auditors in the South African public sector, and this structured approach could reduce their uncertainty about what course of action is appropriate, and the ambiguity inherent in their implementation of the audit plan (Knechel 2007). In this way the IEPM supports professional accountants and auditors with limited skills and experience in the public sector (World Bank 2013). In so doing (improving skills and competence levels), the professional closure experienced as a consequence of apartheid (Murphy 1984) is countered.

The concepts underpinning the IEPM are those of a traditional audit risk approach. This is in contrast with the business risk approach to auditing followed by large audit firms (Fogarty \& Rigsby 2010). In addition to guiding inexperienced auditors (as explained above), a traditional audit risk approach (as incorporated in the IEPM) fits well within the public sector audit environment. Firstly, the AGSA does not blend consulting and auditing (nor do other SAIs). This blending of consulting and auditing is a prominent driver of the current business risk audit approach preferred by large audit firms 
(Fogarty \& Rigsby 2010). Secondly, in terms of the IEPM, the extent of audit evidence gathered and the combinations of audit tests are still determined by the auditor and guided by professional standards; these are not 'managed' so as to produce higher levels of satisfaction for the client, as is the case in business risk auditing (Humphrey \& Moizer 1990). This is an important consideration, because reaction to the social closure legacy of apartheid has resulted in a public sector environment characterised by a tendency to rate racial representation and political loyalty higher than integrity, skills and qualifications, and experience (Koelble \& Siddle 2014; Wenzel 2007). The resulting skills shortage has led to poor audit results and a perilous financial state (Ngoepe \& Ngulube 2014). In such an environment, a traditional audit risk approach, with its focus on audit risk, the financial statements and internal controls, rather than on the auditee's strategic direction (Knechel 2007), ensures an audit approach that searches for those factors that might lead to a misstatement of an account balance, class of transactions or disclosure (Fogarty \& Rigsby 2010). Finally, the IEPM makes use of materiality levels, evaluation of internal controls and audit procedure combinations, while planning for business risk auditing might not lead to a similar responsiveness to proportionate changes in levels of substantive testing and follow-up procedures (Fogarty \& Rigsby 2010).

\section{Conclusion}

This article presents seven building blocks from which a model has been constructed to guide public sector auditors in the exercise of professional judgement in planning decisions for classes of transactions, account balances and/or disclosures. The IEPM clarifies the audit evidence decision sequences and the inter-relationships and contingent dependencies of the different audit procedures, and quantifies the compensatory requirements of the inter-relationships between the types of audit procedures and the desired overall levels of assurance in response to the assessed risks of material misstatement. Although the model is aligned with the current ISAs, it relates better to the traditional audit risk approach than to the currently preferred business risk audit approach of large audit firms (Fogarty \& Rigsby 2010). The IEPM has been included in the audit methodology of the AGSA, and its compliance with the ISA requirements has been assessed through a monitoring inspection performed by the IRBA (Mentz 2014).

When following the IEPM, South African public sector auditors employ a more traditional audit risk approach, in preference to the business risk audit approach used by large audit firms. It is also in contrast to present-day private sector auditors' resistance to formalism and structure (Abdullatif \& Al-Khadash 2010; Khalifa et al. 2007; Knechel 2007). Such a structured approach fits well in the public sector environment, effectively addressing its shortage of experienced professional accountants and auditors (World Bank 2013) (an apartheid legacy). Social closure [institutionalised by the apartheid laws, and a principal form of exclusion (Murphy 1984)], has resulted in a South African public sector that still has significant skills shortages (Koelble \& Siddle 2014; Wenzel 2007) and this continues to result in poor audit results and an ineffectively managed financial state (Ngoepe \& Ngulube 2014). This situation is also faced by SAIs in other developing countries where there are limited skills. This inhibits the performance of the tasks expected of a modern (public sector) auditor (UN 2007) and audit function, as is the case of the AGSA. The outcome is a corruption-stricken public sector environment that is shy of transparency and accountability (Iyoha \& Oyerinde 2010; Kayrak 2008).

The study has acknowledged limitations. The focus of the IEPM developed in this study is at the class of transactions, account balance, disclosure and assertion levels, and not at the overall financial statement level. The model does not consider the business risk assessment (the backbone of business risk auditing) or the evaluation and the reporting phases of the audit, and it is set at the point in the audit sequence after the assessment of risk at the relevant class of transactions, account balance, disclosure and assertion level has been completed. It is specifically concerned with quantifying the extent or sufficiency of audit evidence required to enable the public sector auditor to express an opinion on the financial statements, and it limits the consideration of the nature and timing of audit procedures only to the degree that they impact the auditor's decisions regarding the extent of audit evidence.

Future studies should consider developing a business risk audit approach for use by public sector auditors that makes use of significantly detailed risk assessments at all levels of inquiry (including corruption and political influences at each level) and that shows clear linkages between audit procedures and risk assessments. These studies should also consider how inexperienced auditors and auditors with limited skills could be developed to follow the revised business risk audit approach. Another area of consideration is the impact of such an approach on the mandate of SAIs, particularly because past results have shown that regulatory changes (such as the Sarbanes-Oxley Act in the USA) that required improved regulatory scrutiny have caused auditors to act with greater circumspection while following a business risk audit approach (Fogarty \& Rigsby 2010). This line of research would require renewed consideration of the relations between SAIs, their states and regulatory agencies and the users of public sector financial information. In this regard, a future study should investigate the logic of professionalism among public sector auditors as it will determine how public sector auditors ought to act, how SAIs should be organised and how professional norms are best enforced (Suddaby, Gendron \& Lam 2009).

\section{Acknowledgements Competing interests}

The authors declare that they have no financial or personal relationships which may have inappropriately influenced them in writing this article. 


\section{Authors' contributions}

M.M., K.B and E.O. equally contributed to the research and writing of this article.

\section{References}

Abdullatif, M. \& Al-Khadash, H.A., 2010, 'Putting audit approaches in context: The case of business risk audits in Jordan', International Journal of Auditing 14, 1-24. https://doi.org/10.1111/j.1099-1123.2009.00400.x

Acito, A.A., Burks, J.J. \& Johnson, W.B., 2009, 'Materiality decisions and the correction of accounting errors', Accounting Review 84(3), 659-688. https://doi.org/10.2308/ accr.2009.84.3.659

Akinyemi, O., 2010, 'Factors associated with employment status among graduates in South Africa', Eastern Africa Social Science Research Review 26(2), 77-91. https:// South Africa', Eastern Africa
doi.org/10.1353/eas.0.0020

Akoojee, S., 2010, 'Intermediate skills development in South Africa: Understanding the context, responding to the challenge', in O. Edigheji (ed.), Constructing a democratic developmental state in South Africa: Potentials and challenges, $\mathrm{pp}$. 261-282, HSRC, Cape Town.

Akresh, A.D., 2010, 'A risk model to opine on internal control', Accounting Horizons 24(1), 65-78. https://doi.org/10.2308/acch.2010.24.1.65

American Institute of Certified Public Accountants, 2008, Audit guide: Audit sampling, AICPA, New York.

Annisette, M., 1999, 'Importing accounting: The case of Trinidad and Tobago' Accounting, Business and Financial History 9(1), 103-133. https://doi.org/ Accounting, Business and
$10.1080 / 095852099330386$

Annisette, M., 2003, 'The colour of accountancy: Examining the salience of race in a professionalization project', Accounting, Organizations \& Society 28, 639-674. https://doi.org/10.1016/S0361-3682(02)00030-2

Arens, A.A., Eler, R.J. \& Beasley, M.S., 2012, Auditing and assurance services, Pearson London.

Association of Certified Fraud Examiners, 2014, Report to the nations on occupationa fraud and abuse, viewed 21 March 2016, from http://www.acfe.com/rttn/docs/ 2014-report-to-nations.pdf

Auditor-General South Africa, 2015a, 2014-15 Integrated annual report, viewed 23 March 2016, from https://www.agsa.co.za/Documents/AGSAreports/AGSAsannualreports. aspx

Auditor-General South Africa, 2015b, Auditor-general reports a noticeable, improving trend in local government audit results [Press release], viewed 23 March 2016 , from https://www.agsa.co.za/Portals/0/MFMA\%202013-14/MFMA\%2020132014/Media\%20releases/MFMA\%202013-14\%20Media\%20release1.pdf

Barac, K., 2015, 'Helping disadvantaged students: Findings from the Thuthuka programme', Accounting Education an International Journal 24(2), 75-101. https://doi.org/10.1080/09639284.2015.1010171

Bedard, J.C. \& Graham, L.E., 2002, 'The effects of decision aid orientation on risk factor identification and audit test planning', Auditing 21(2), 39-56. https://doi. org/10.2308/aud.2002.21.2.39

Bell, T.B., Peecher, M.E. \& Solomon, I., 2005, The 21st century public company audit, University of Illinois at Urbana-Champaign and KPMG Peat Marwick, Urbana, IL.

Bierstaker, J., Houston, R. \& Wright, A., 2006, 'The impact of competition on audit planning, review and performance', Journal of Accounting Literature 25, 1-58.

Blay, A., Kizirian, T. \& Sneather, L.D., 2008, 'Evidential effort and risk assessment in auditing', Journal of Business and Economics Research 6(9), 39-52.

Blokdijk, H., Drieenhuizen, F. \& Dan, A., 2003, Factors affecting auditors' assessments of planning materiality', Auditing 22(2), 297-307. https://doi.org/10.2308/ aud.2003.22.2.297

Bonnin, D. \& Ruggunan, S., 2013, 'Towards a South African sociology of professions', South African Review of Sociology 44(2), 1-6. https://doi.org/10.1080/21528586. 2013.802533

Bowlin, K., 2011, 'Risk-based auditing, strategic prompts and auditor sensitivity to the strategic risk of fraud', Accounting Review 86(4), 1231-1253. https://doi. strategic risk of fraud',
org/10.2308/accr-10039

Brewster, B.E., 2011, 'How a systems perspective improves knowledge acquisition and performance in analytical procedures', The Accounting Review 86(3), 915-943. https://doi.org/10.2308/accr.00000040

Budescu, D.V., Peecher, M.E. \& Solomon, I., 2012, 'The joint influence of the extent and nature of audit evidence, materiality thresholds and misstatement type on achieved audit risk', Auditing 31(2), 19-41. https://doi.org/10.2308/ajpt-10239

Canadian Institute of Chartered Accountants, 1980, Extent of audit testing, CICA, Toronto.

Causholli, M. \& Knechel, W.R., 2012, 'An examination of the credence attributes of an audit', Accounting Horizons 26(4), 631-656. https://doi.org/10.2308/acch-50265

Charles, S.L., Glover, S.M. \& Sharp, N.Y., 2010, 'The association between financial reporting risk and audit fees before and after the historic events surrounding SOX', Auditing 29(1), 15-39. https://doi.org/10.2308/aud.2010.29.1.15

Cho, S. \& Lew, A.Y., 2000, 'Analytical review applications among large audit firms in Hong Kong', Managerial Auditing Journal 15(8), 431-438. https://doi. org/10.1108/02686900010354736

Christensen, B.E., Elder, R.J. \& Glover, S.M., 2015, 'Insights into large audit firm sampling policies', Current Issues in Auditing 9(2), 7-18. https://doi.org/10.2308/
ciia-51223
Chua, W.F. \& Poullaos, C., 1993, 'Rethinking the profession-state dynamic: The case of the Victorian charter attempt 1885-1906', Accounting Organizations and Society the Victorian charter attempt, 1885-1906', Accounting, Organizations
18(7-8), 691-728. https://doi.org/10.1016/0361-3682(93)90049-C

Colbert, J.L., 2001, 'Audit sampling', Internal Auditor 58(1), 27-29.

Cooper, D.J. \& Robson, K., 2006, 'Accounting, professions and regulation: Locating the sites of professionalization', Accounting, Organizations and Society 31, 415-444. https://doi.org/10.1016/j.aos.2006.03.003

Curtis, E. \& Turley, S., 2007, 'The business risk audit: A longitudinal case study of an audit engagement', Accounting, Organizations and Society 32(4-5), 439-461. https://doi.org/10.1016/j.aos.2006.09.004

Dănescu, T. \& Spătăcean, O., 2009, 'Analytical procedures used in financial audit for the valuation of portfolio performances: Case of financial investment companies', Annales Universitatis Apulensis: Series Oeconomica 11(1), 24-31.

De Martinis, M., Fukukawa, H. \& Mock, T.J., 2011, 'Exploring the role of country and client type on the auditor's client risk assessments and audit planning decisions',
Managerial Auditing Journal 26(7), 543-565. https://doi.org/10.1108/0268 Managerial Audi1151305

Del Corte, J.M., Garcia, F.J.M. \& Laviada, A.F., 2010, 'Effective use of qualitative materiality factors: Evidence from Spain', Managerial Auditing Journal 25(5), materiality factors: Evidence from Spain', Managerial
458-483. https://doi.org/10.1108/02686901011041849

Desta, Y., 2006, 'Designing anti-corruption strategies for developing countries: A country study of Eritrea', Journal of Developing Societies 22(4), 421-449. https:// doi.org/10.1177/0169796X06072568

Dixon, J., Durrheim, K., Tredoux, C., Tropp, L., Clack, B. \& Eaton, L., 2010, 'A paradox of integration? Interracial contact, prejudice reduction, and perceptions of racial discrimination', Journal of Social Issues 66(2), 401-416. https://doi.org/10.1111/ j.1540-4560.2010.01652.x

Edigheji, O., 2010, Constructing a democratic developmental state in South Africa: Potentials and challenges, HSRC, Cape Town.

Eilifsen, A., Messier, W.F., Glover, S.M. \& Prawitt, D.F., 2010, Auditing and assurance services, 2nd edn., McGraw-Hill, London.

Elder, R.J. \& Allen, R.D., 2003, 'A longitudinal field investigation of auditor risk assessments and sample size decisions', Accounting Review 78(4), 983-1002. assessments and sample size decisions', $A$ cco
https://doi.org/10.2308/accr.2003.78.4.983

El-Masry, E.E. \& Hansen, K.A., 2008, 'Factors affecting auditors' utilization of evidential cues', Managerial Auditing Journal 23(1), 26-50. https://doi.org/10.1108/ 02686900810838155

Fogarty, J.A., Graham, L. \& Schubert, D.R., 2006, 'Assessing and responding to risks in a financial statements audit: Part I', Journal of Accountancy 202(1), 43-49.

Fogarty, J.A., Graham, L. \& Schubert, D.R., 2007, 'Assessing and responding to risks in a financial statements audit: Part II', Journal of Accountancy 203(1), 59-64.

Fogarty, T.J. \& Rigsby, J.T., 2010, 'A reflective analysis of the "new audit" and the public interest: The revolutionary innovation that never came', Journal of Accounting \& Organizational Change 6(3), 300-329. https://doi.org/10.1108/18325911011 075204

Fukukawa, H. \& Mock, T.J., 2011, 'Audit risk assessments using belief versus probability', Auditing: A Journal of Practice and Theory 30(1), 75-99. https://doi. org/10.2308/aud.2011.30.1.75

Fukukawa, H., Mock, T.J. \& Wright, A., 2006, 'Audit programs and audit risk: A study of Japanese practice', International Journal of Auditing 10(1), 41-65. https://doi. Japanese practice', International Journ
org/10.1111/j.1099-1123.2006.00298.x

Glover, S.M., Prawitt, D.F., Wilks, T.J. \& McDaniel, L., 2005, 'Why do auditors over-rely on weak analytical procedures? The role of outcome and precision', Auditing 24, 197-220.

Hall, T.W., Hunton, J.E. \& Pierce, B.J., 2002, 'Sampling practices of auditors in public accounting, industry, and government', Accounting Horizons 16(2), 125-136. https://doi.org/10.2308/acch.2002.16.2.125

Hammond, T., Clayton, B.M. \& Arnold, P.J., 2009, 'South Africa's transition from apartheid: The role of professional closure in the experiences of black chartered accountants', Accounting, Organizations and Society 34, 705-721. https://doi. org/10.1016/j.aos.2008.09.002

Hammond, T., Clayton, B.M. \& Arnold, P.J., 2012, “An "unofficial” history of race relations in the South African accounting industry, 1968-2000: Perspectives of South Africa's first black chartered accountants', Critical Perspectives on Accounting 23, 332-350. https://doi.org/10.1016/j.cpa.2011.10.005

Hayes, A., 2007, 'Audit huddles as a tool to control over- and under-auditing tendencies: Part I', Journal of Government Financial Management Spring, 58-59.

Heathcote, K., 2012, 'The professionalization efforts of accountants in the Orange Free State, 1907-1927: An exploration of their first twenty years', New Contree 64, 31-55.

Hitzig, N.B., 2004, 'The hidden risk in analytical procedures: What WorldCom revealed', CPA Journal 74(2), 32-35.

Hogan, C.E. \& Wilkins, M.S., 2008, 'Evidence on the audit risk model: Do auditors increase audit fees in the presence of internal control deficiencies?', Contemporary Accounting Research 25(1), 219-242. https://doi.org/10.1506/car.25.1.9

Hoogduin, L.A., Hall, T.W. \& Tsay, J.J., 2010, 'Modified sieve sampling: A method for single- and multi-stage probability-proportional-to-size sampling', Auditing 29(1), 125-148. https://doi.org/10.2308/aud.2010.29.1.125

Hooks, K.L., 2011, Auditing and assurance services: Understanding the integrated audit, Wiley, New York.

Houghton, K.A., Jubb, C. \& Kend, M., 2011, 'Materiality in the context of audit: The real expectations gap', Managerial Auditing Journal 26(6), 482-500. https://doi. org/10.1108/02686901111142549 
Humphrey, C. \& Moizer, P., 1990, 'From techniques to ideologies: An alternative perspective on the audit function', Critical Perspectives on Accounting 1(3) perspective on the audit function', Critical Perspectives
217-238. https://doi.org/10.1016/1045-2354(90)03021-7

International Accounting Standards Board, 2015 Conceptual framework for financial reporting, SAICA handbook, SAICA, Johannesburg.

International Auditing and Assurance Standards Board, 2015a, International framework for assurance engagements. SAICA handbook, SAICA, Johannesburg.

International Auditing and Assurance Standards Board, 2015b, ISA 200: Overall objectives of the independent auditor and the conduct of an audit in accordance with International Standards on Auditing, SAICA handbook, SAICA, Johannesburg.

International Auditing and Assurance Standards Board, 2015c, ISA 315: Identifying and assessing the risks of material misstatement through understanding the entity and its environment. SAICA handbook, SAICA, Johannesburg.

International Auditing and Assurance Standards Board, 2015d, ISA 320: Materiality in planning and performing an audit. SAICA handbook, SAICA, Johannesburg.

International Auditing and Assurance Standards Board, 2015e, ISA 330: The auditor's responses to assessed risks. SAICA handbook, SAICA, Johannesburg.

International Auditing and Assurance Standards Board, 2015f, ISA 450: Evaluation of misstatements identified during the audit. SAICA handbook, SAICA, Johannesburg.

International Auditing and Assurance Standards Board, 2015g, ISA 520: Analytical procedures. SAICA handbook, SAICA, Johannesburg.

International Auditing and Assurance Standards Board, 2015h, ISA 530: Audit sampling. SAICA handbook, SAICA, Johannesburg.

International Federation of Accountants, 2011, Guide to using ISAs in the audits of small- and medium-sized entities: Volume 2, 3rd edn., IFAC, New York.

Iyoha, F.O. \& Oyerinde, D., 2010, ,Accounting infrastructure and accountability in the management of public expenditure in developing countries: A focus on Nigeria', Critical Perspectives on Accounting 21,361-373. https://doi.org/10.1016/j. critical Perspective

Jeppesen, K.K., 2007, 'Organizational risk in large audit firms', Managerial Auditing Journal 22(6), 590-603. https://doi.org/10.1108/02686900710759398

Johnstone, K.M. \& Bedard, J.C., 2001, 'Engagement planning, bid pricing and client response in the market for initial attest engagements', Accounting Review 76(2), 199-220. https://doi.org/10.2308/accr.2001.76.2.199

Kayrak, M., 2008, 'Evolving challenges for supreme audit institutions in struggling with corruption', Journal of Financial Crime 15(1), 60-70. https://doi.org/10.1108/135 90790810841707

Khalifa, R., Sharma, N., Humphrey, C. \& Robson, K., 2007, 'Discourse and audit change: Transformations in methodology in the professional audit field', Accounting Auditing and Accountability Journal 20(6), 825-854. https://doi.org/10.1108/ 09513570710830263

Kim, S.N., 2004, 'Imperialism without empire: Silence in contemporary accounting research on race/ethnicity', Critical Perspectives on Accounting 15, 95-133. https://doi.org/10.1016/S1045-2354(03)00004-2

Kinney, W.R., 1979, 'Integrating audit tests: Regression analysis and partitioned dollarunit sampling', Journal of Accounting Research 17(2), 456-475. https://doi. org/10.2307/2490513

Kinney, W.R., 2005, 'Twenty-five years of audit deregulation and re-regulation: What does it mean for 2005 and beyond?', Auditing 24, 89-109.

Kinney, W.R. \& McDaniel, L.S., 1996, 'How to improve effectiveness of substantive analytical procedures', CPA Journal 66(4), 52-54.

Kleinman, G., Lin, B.B. \& Palomon, D., 2014, Audit quality: A cross-national comparison of audit regulatory regimes', Journal of Accounting, Auditing \& Finance 29(1), 61-87. https://doi.org/10.1177/0148558X13516127

Knechel, W.R., 2000, 'Behavioral research in auditing and its impact on audit education', Issues in Accounting Education 15(4), 695-712. https://doi. org/10.2308/iace.2000.15.4.695

Knechel, W.R., 2007, 'The business risk audit: Origins, obstacles and opportunities' Accounting, Organizations and Society 32, 383-408. https://doi.org/10.1016/j. aos.2006.09.005

Knechel, W.R., Krishnan, G.V., Pevzner, M., Shefchik, L.B. \& Velury, U.K., 2013, 'Audit quality: Insights from the academic literature', Auditing: A Journal of Practice \& Theory 32 (Suppl 1), 385-421. https://doi.org/10.2308/ajpt-50350

Koelble, T.A. \& Siddle, A., 2014, 'Decentralization in post-apartheid South Africa', Regional \& Federal Studies 24(5), 607-623. https://doi.org/10.1080/13597566.20 14.971773

Koskivaara, E., 2007, 'Integrating analytical procedures into the continuous audit environment', Journal of Information Systems and Technology Management 3(3), environment', Journal of Information Systems and Technology Nar
331-346. https://doi.org/10.4301/S1807-17752006000300005

Lee, T.A., 2010, 'Social closure and the incorporation of the Society of Accountants in Edinburgh in 1854', Accounting, Business \& Financial History 20(1), 1-22. https:// doi.org/10.1080/09585200903504181

Leedy, P.D. \& Ormrod, J.E., 2014, Practical research: Planning and design, 10th edn., Pearson, Upper Saddle River, NJ.

Lin, K.Z. \& Fraser, I.A.M., 2003, 'The use of analytical procedures by external auditors in Canada', Journal of International Accounting, Auditing \& Taxation 12(2) 153-168. https://doi.org/10.1016/j.intaccaudtax.2003.08.002

Luo, L., 2011, 'Are audit programs responsive to audit risk?', Unpublished doctoral thesis, University of Alberta, Canada.

Macdonald, K.M., 1984, 'Professional formation: The case of Scottish accountants', The British Journal of Sociology 35(2), 174-189. https://doi.org/10.2307/590231
Malsch, B., Gendron, Y. \& Grazzini, F., 2011, ,Investigating interdisciplinary translations: The influence of Pierre Bourdieu on accounting literature', Accounting, Auditing \& Accountability Journal 24(2), 194-228. https://doi.org/10.1108/09513571111 100681

McDaniel, L.S. \& Simmons, L.E., 2007, 'Auditors' assessment and incorporation of expectation precision in evidential analytical procedures', Auditing: A Journal of Practice and Theory 26(1), 1-18. https://doi.org/10.2308/aud.2007.26.1.1

Mdepa, W. \& Tshiwula, L., 2012, 'Student diversity in South African higher education' Widening Participation and Lifelong Learning 13, 19-34. https://doi.org/10.5456/ WPLL.13.S.19

Mentz, M., 2014, 'An integrated audit evidence planning model to quantify the extent of audit evidence', Unpublished doctoral thesis, University of South Africa, South Africa.

Messier, W.F., Glover, S.M. \& Prawitt, D.F., 2010, Auditing and assurance services: A systematic approach, 7th edn., McGraw-Hill, New York.

Messier, W.F., Martinov-Bennie, N. \& Eilifsen, A., 2005, 'A review and integration of empirical research on materiality: Two decades later', Auditing 24(2), 153-187. https://doi.org/10.2308/aud.2005.24.2.153

Messier, W.F., Simon, C.A. \& Smith, J.L., 2013, 'Two decades of behavioral research on analytical procedures: What have we learned?', Auditing: A Journal of Practice and Theory 32(1), 139-181. https://doi.org/10.2308/ajpt-50327

Murphy, R., 1984, 'The structure of closure: A critique and development of the theories of Weber, Collins, and Parkin', The British Journal of Sociology 35(4), 547-567. https://doi.org/10.2307/590434

Nelson, M., Tan, H. \& Trotman, K.T., 2005, 'Judgement and decision making research in auditing: A task, person, and interpersonal interaction perspective', Auditing 24, 41-71. https://doi.org/10.2308/aud.2005.24.Supplement.41

Ngoepe, M. \& Ngulube, P., 2014, 'The need for records management in the auditing process in the public sector in South Africa', African Journal of Library, Archives \& Information Science 24(2), 135-150.

O'Reilly, V.M., Winograd, B.N., Gerson, J.S. \& Jaenicke, H.R., 1999, Montgomery's auditing, 12th edn., Wiley, New York.

Perry, T.P.M., 2011, SAS 106: Audit evidence: Is it effective?, viewed from 23 March 2016, http://papers.ssrn.com/sol3/papers.cfm?abstract_id=1907438

Pillay, S., 2004, 'Corruption - The challenge to good governance: A South African perspective', The International Journal of Public Sector Management 17(7) 586-605. https://doi.org/10.1108/09513550410562266

Pym, J. \& Kapp, R., 2013, 'Harnessing agency: Towards a learning model for undergraduate students', Studies in Higher Education 38(2), 272-284. https://doi. org/10.1080/03075079.2011.582096

Republic of South Africa, 1996, Constitution of the Republic of South Africa, 1996, Government printer, Pretoria.

Republic of South Africa, 2004, Public Audit Act, 2004, Government printer, Pretoria.

Samaha, K. \& Hegazy, M., 2010, 'An empirical investigation of the use of ISA 520 "analytical procedures" among big 4 versus non-big 4 audit firms in Egypt', Managerial Auditing Journal 25(9), 882-911. https://doi.org/10.1108/0268 6901011080053

Sartorius, K. \& Sartorius, B., 2013, 'The comparative performance of chartered accountancy students in South Africa: The impact of historical legacies', Development Southern Africa 30(3), 401-416. https://doi.org/10.1080/037683 5X.2013.817307

Schmutte, J. \& Duncan, J.R., 2009, 'Professional judgement: A model for accounting and auditing decisions', CPA Journal 79(9), 32-35.

Seidel, T., 2014, 'The effective use of the audit risk model at the account level', Unpublished doctoral thesis, University of Arkansas, Fayetteville, AR

South African Institute of Chartered Accountants, 2016, Membership statistics, viewed 23 March 2016, from https://www.saica.co.za/Members/AboutMembers/ MembershipStatistics/tabid/502/language/en-ZA/Default.aspx

Srinidhi, B.N. \& Vasarhelyi, M.A., 1986, 'Auditor judgement concerning establishment of substantive tests based on internal control reliability', Auditing 5(2), 64-76.

Strauss, A. \& Corbin, J., 2008, Basics of qualitative research: Techniques and procedures for developing grounded theory, 3rd edn., Sage, London.

Suddaby, R., Gendron, Y. \& Lam, H., 2009, 'The organizational context of professionalism in accounting', Accounting, Organizations and Society 34, 409-427. https://doi.org/10.1016/j.aos.2009.01.007

Transparency International, 2014, Corruption Perceptions Index 2014: Results, viewed 21 March 2016, from http://www.transparency.org/cpi2014/results\#myAnchor1

Trompeter, G. \& Wright, A., 2010, 'The world has changed: Have analytical procedure practices?', Contemporary Accounting Research 27(2), 669-700. https://doi. org/10.1111/j.1911-3846.2010.01021.x

Turley, S. \& Cooper, M., 1991, Auditing in the United Kingdom: A study of development in the audit methodologies of large accounting firms, ICAEW, London.

United Nations, 2007, Auditing for social change: A strategy for citizen engagement in public sector accountability, UN, New York.

Verhoef, G., 2013, 'Reluctant ally: The development of statutory regulation of the accountancy profession in South Africa, 1904-1951', Accounting History 18(2), 163-191. https://doi.org/10.1177/1032373212471168

Wang, T. \& Cuthbertson, R., 2014, 'Eight issues on audit data analytics we would like researched', Journal of Information Systems 29(1), 155-162. https://doi. org/10.2308/isys-50955

Wenzel, P., 2007, 'Public-sector transformation in South Africa: Getting the basics right', Progress in Development Studies 7(1), 47-64. https://doi.org/10.1177/1464 99340600700105 
Whittington, O.R. \& Pany, K., 2010, Principles of auditing and other assurance services, 7th edn., McGraw-Hill, New York.

Wilson, A.C. \& Colbert, J., 1989, 'An analysis of simple and rigorous decision models as analytical procedures', Accounting Horizon 3(4), 79-83.

World Bank, 2013, South Africa report on the observance of standards and codes accounting and auditing, viewed 23 March 2016, from http://www.worldbank. org/ifa/South_Africa_rosc_Accounting_and_Auditing.pdf
World Economic Forum, 2015a, Global Information Technology Report 2015, viewed 21 March 2016, from https://www.weforum.org/reports/global-informationtechnology-report-2015

World Economic Forum, 2015b, The global competitiveness index 2015-2016, viewed 21 March 2016, from http://reports.weforum.org/global-competitivenessreport-2015-2016/the-global-competitiveness-index-2015-2016/

Zabel, R.B. \& Benjamin, J.J., 2002, 'Reviewing materiality in accounting fraud', New York Law Journal 15, 1-4. 